\title{
Antibacterial Inhibitory Effects of Punica Granatum Gel on Cariogenic Bacteria: An in vitro Study
}

\author{
${ }^{1}$ Grazielle Millo, ${ }^{2}$ Apa Juntavee, ${ }^{3}$ Ariya Ratanathongkam, ${ }^{4}$ Natsajee Nualkaew \\ ${ }^{5}$ Jomjai Peerapattana, ${ }^{6}$ Supaporn Chatchiwiwattana
}

\begin{abstract}
Aim: This study evaluated the in vitro antibacterial effects of the formulated Punica granatum (PG) gel against Streptococcus mutans, Streptococcus sanguinis, and Lactobacillus casei.

Materials and methods: The PG extract was dissolved in water at $500 \mathrm{mg} / \mathrm{mL}$. High performance liquid chromatography (HPLC) was used for identification and quantification of chemical marker punicalagin. Minimum bactericidal concentration (MBC) and time-kill assay (TKA) were investigated. Antibacterial activities of the formulated PG gel, $2 \%$ chlorhexidine $(\mathrm{CHX})$ gel and blank gel were tested by measuring the zones of inhibition through agar well diffusion method.
\end{abstract}

Results: The HPLC results showed presence of punicalagin at $2023.58 \pm 25.29 \mu \mathrm{g} / \mathrm{mL}$ in the aqueous PG extract and at $0.234 \%(\mathrm{w} / \mathrm{w})$ in the formulated $P G$ gel. The MBC for S. mutans, S. Sanguinis, and $L$. casei were 250,125 , and $500 \mathrm{mg} / \mathrm{mL}$ respectively. The TKA of $500 \mathrm{mg} / \mathrm{mL}$ aqueous PG extract showed total inhibition of $S$. mutans, S. Sanguinis, and L. casei at 6,1 , and 24 hours contact time respectively. Agar well diffusion revealed that for $\mathrm{S}$. mutans, $\mathrm{CHX}$ gel > PG gel > blank gel; for $S$. sanguinis, $\mathrm{CHX}$ gel = PG gel > blank gel; for L. casei, $\mathrm{CHX}$ gel > PG gel = blank gel. Comparison of the PG gel potency showed that $S$. sanguinis $=S$. mutans $>L$. casei.

Conclusion: The PG gel equivalent to $0.234 \%$ punicalagin (w/w) inhibited S. mutans and S. sanguinis but not L. casei within 24 hours incubation period and has the potential to be used for caries prevention.

Keywords: Antibacterial, Punica grantum gel, Punicalagin, Streptococcus mutans.

\footnotetext{
${ }^{1}$ Graduate Student, ${ }^{2,3,5,6}$ Associate Professor, ${ }^{4}$ Assistant Professor

1,2Department of Pediatric Dentistry, Faculty of Dentistry, Khon Kaen University, Khon Kaen, Thailand

${ }^{3,6}$ Department of Oral Biology, Faculty of Dentistry, Khon Kaen University, Khon Kaen, Thailand

${ }^{4}$ Department of Pharmacognosy and Toxicity, Faculty of Pharmaceutical Sciences, Khon Kaen University, Khon Kaen Thailand

${ }^{5}$ Department of Pharmaceutical Technology, Faculty of Pharmaceutical Sciences, Khon Kaen University, Khon Kaen Thailand

Corresponding Author: Apa Juntavee, Associate Professor Department of Pediatric Dentistry, Faculty of Dentistry, Khon Kaen University, Khon Kaen, Thailand, Phone: +0066815447360 e-mail: apa.edu@hotmail.com
}

How to cite this article: Millo G, Juntavee A, Ratanathongkam A, Nualkaew N, Peerapattana J, Chatchiwiwattana S. Antibacterial Inhibitory Effects of Punica Granatum Gel on Cariogenic Bacteria: An in vitro Study. Int J Clin Pediatr Dent 2017;10(2):152-157.

Source of support: Nil

Conflict of interest: None

\section{INTRODUCTION}

Dental caries has been identified as one of the most prevalent chronic conditions and is a major problem for children all over the world. ${ }^{1}$ Untreated caries in deciduous teeth was the 10th most prevalent medical condition, affecting $9 \%$ of the global population. ${ }^{2}$ Caries is characterized by an early acquisition and overgrowth of several species of cariogenic bacteria, such as Streptococcus mutans, Streptococcus sanguinis, and Lactobacillus casei.

Streptococcus mutans, the primary etiologic factor for dental caries, causes demineralization of inorganic tooth structure by metabolizing sucrose to lactic acid. It can also colonize tooth surfaces and initiate plaque formation through their ability to synthesize and bind extracellular polysaccharides (glucan) using the enzyme glucosyltransferase. ${ }^{3-5}$ Streptococcus sanguinis initiates the aggregation of other oral bacteria and cause maturation of the dental plaque, while L. casei is commonly found in advanced caries lesions extending to dentin. ${ }^{6-9}$ Several antibiotics and antimicrobial agents, such as chlorhexidine (CHX) has been used to eliminate cariogenic bacteria from the oral flora. However, their clinical use is limited due to undesirable side effects including microorganism susceptibility, vomiting, diarrhea, and tooth staining. ${ }^{10,11}$ These problems stressed the importance of further research to develop alternative antibacterial agents from natural sources with focus on safety for humans and efficacy in the treatment and prevention of dental caries.

Punica granatum (PG), commonly known as pomegranate, is widely renowned for its variety of therapeutic effects and is relatively low-cost and locally available in most of the Southeast Asian countries. ${ }^{12}$ Pomegranate is also documented to have minimal toxicity and adverse effects. ${ }^{13-15}$ Studies have shown that PG has antimicrobial effects against different microorganisms. ${ }^{16-18}$ However, not enough information is available concerning the 
in vitro antimicrobial effect of a formulated PG gel against cariogenic microorganisms specifically S. mutans, S. sanguinis, and L. casei.

\section{AIM}

This study aimed to evaluate and compare the in vitro antibacterial effects of the formulated PG gel against planktonic forms of cariogenic bacteria, such as S. mutans, S. sanguinis, and L. casei.

\section{MATERIALS AND METHODS}

\section{Preparation of the PG Extract Sample}

Punica granatum extract powder extracted from pomegranate pericarp ( $\left.\mathrm{NuSci}^{\circledR}, \mathrm{USA}\right)$ was dissolved in distilled water at a $500 \mathrm{mg} / \mathrm{mL}$ concentration. The mixture was shaken in a vortex mixer for 1 minute and centrifuged at $10,000 \times \mathrm{g}$ for 10 minutes at $25^{\circ} \mathrm{C}$. The supernatant was then filtered through a nylon filter with pore size 0.45 $\mu \mathrm{m}$ prior to further testing and laboratory investigation.

\section{High Performance Liquid Chromatography}

High Performance Liquid Chromatography (HPLC) analysis was carried out using Agilent 1100 series equipped with an Agilent 1100 series photodiode array detector and autosampler (Agilent Technologies, USA) with a reversed phase $4 \mathrm{~mm}$ internal diameter $\times 250 \mathrm{~mm}$ length, Kromasil $5 \mu \mathrm{m}$ 100A C18 column (Phenomenex, USA). The mobile phase consisted of solvent A: $0.1 \%$ trifluoroacetic acid (Sigma-Aldrich, USA) in water and solvent B: Methanol (Merck, Germany) with an elution profile modified from Madrigal-Carballo et $\mathrm{al}^{19}: 100$ to $73 \%$ solvent A for 30 minutes, 73 to $45 \%$ solvent $\mathrm{A}$ for the next 15 minutes, 45 to $0 \%$ solvent $\mathrm{A}$ for 5 minutes, maintained $0 \%$ solvent $\mathrm{A}$ for 10 minutes followed by a 10 minutes re-equilibration time back to $100 \%$ solvent $\mathrm{A}$. Flow rate was set at $1 \mathrm{~mL} /$ minute and $20 \mu \mathrm{L}$ of the sample was injected into the column per cycle. The UV detector was set at $254 \mathrm{~nm}$ at $25^{\circ} \mathrm{C}$. Punicalagin analytic standard of $98 \%$ purity (Sigma-Aldrich, USA) was extracted from pomegranate. A series of 25 to $200 \mu \mathrm{g}$ / $\mathrm{mL}$ punicalagin standard was diluted in water to make the calibration curve and method validation experiments.

\section{Bacterial Culture}

Standard strains of S. mutans (DMST18777) and S. sanguinis (DMST18782) from National Institute of Health, Thailand were prepared and cultured separately in Todd Hewitt Broth (THB, Bacto ${ }^{\mathrm{TM}}$, USA) and Mitis Salivarius Agar (MSA) (Difco ${ }^{\mathrm{TM}}$, USA). Lactobacillus casei (BCC36987) purchased from Biotec, Thailand were prepared and cultured in de Man, Rogosa, and Sharpe (MRS) broth and agar (Difco ${ }^{\mathrm{TM}}$, USA). The bacteria were maintained in a $5 \% \mathrm{CO}_{2}$ incubator at $37^{\circ} \mathrm{C}$.

\section{Minimum Bactericidal Concentration}

Minimum inhibitory concentration was determined by using broth microdilution assay. An aqueous stock solution of PG extract at $1000 \mathrm{mg} / \mathrm{mL}$ concentration was prepared and filtered. The PG extract mixture was prepared one step higher than the final dilution range required to compensate for the addition of an equal volume of inoculum. Two-fold serial dilutions of filtered PG extract were prepared with the appropriate broth medium specific for each of the bacterial strains at a total volume of $100 \mu \mathrm{L}$ per well in 96-well polystyrene microtiter plates. The final concentrations of PG extract ranged decreasingly from 500 to $62.5 \mathrm{mg} / \mathrm{mL}$. The microtiter plate wells were then inoculated with each bacterial strain separately.

After incubation at $37^{\circ} \mathrm{C}$ with $5 \% \mathrm{CO}_{2}$ for 24 hours, $10 \mu \mathrm{L}$ drop from each well were dispensed in selective culture agar for each bacteria and allowed to incubate for another 24 hours at the same conditions as previously done. The lowest concentration of antimicrobial agent that prevented the growth of an organism after subculture on to antibiotic-free media was considered to be the minimum bactericidal concentration (MBC). All experiments were conducted in triplicate.

\section{Time-kill Assay}

About $500 \mathrm{mg} / \mathrm{mL}$ concentration of the PG extract was mixed with each bacteria separately. To determine the time-kill effects, $100 \mu \mathrm{L}$ of mixture from each exposure time of $0,1,6,8,12$, and 24 hour were taken, neutralized, and diluted 10 -fold with phosphate buffer solution. In triplicate, $10 \mu \mathrm{L}$ of the diluted samples were dispensed in selective culture media using the drop plate technique and incubated at $37^{\circ} \mathrm{C}$ with $5 \% \mathrm{CO}_{2}$ for 24 hours. The total viable colonies (CFU/mL) were counted and $\log _{10}$ reductions were determined for each time point as compared to a negative control where no extract was added to the bacterial mixture.

\section{Agar Well Diffusion}

Using the pour plate technique, $20 \mathrm{~mL}$ of Mueller-Hinton agar were seeded with $500 \mu \mathrm{L}$ of $S$. mutans and was poured into sterile glass petri dishes and allowed to solidify completely. The same preparatory steps were done using MSA and MRS agar for S. sanguinis, and L. casei respectively. After the medium was solidified, 3 wells of $6 \mathrm{~mm}$ diameter $\times 6 \mathrm{~mm}$ height were made in each of the plates with 
the use of a sterile borer. One well was for the formulated PG gel, the other was for blank gel, and the other for the positive control $2 \% \mathrm{CHX}$ gel. The plates were incubated overnight at $37^{\circ} \mathrm{C}$ in $5 \% \mathrm{CO}_{2}$ condition. Inhibition of bacterial growth was determined by measuring the diameter of the zone of inhibition (ZOI) around each of the wells.

\section{Data Analysis}

Statistical package for the social sciences version $19^{\circledR}$ for Windows was used in data analysis. Descriptive statistics that included means, standard deviation, percentage (\%), and $\log _{10}$ values were used. One way repeated measures analysis of variance (ANOVA) with post hoc Bonferroni test were used to compare the bacterial growth inhibition by PG gel, positive control 2\% CHX gel, and blank gel in each of the bacterial strains. Comparison of bacterial growth inhibition by PG gel in the tested bacterial strains were done using one way ANOVA followed by post hoc Tamhane's T2 test for multiple comparisons where equal variances were not assumed. Significance level is set at 0.05 .

\section{RESULTS}

\section{High Performance Liquid Chromatography}

The HPLC method for determination of punicalagin content in the sample used in this study was successfully validated as summarized in Table 1 . All parameters were within the acceptable limits. ${ }^{20}$ The peaks for punicalagins $\mathrm{A}$ and $\mathrm{B}$ were identified and quantified in the prepared $50 \mathrm{mg} / \mathrm{mL}$ diluted aqueous PG extract sample which were similar to the retention times of the peaks found in the $200 \mu \mathrm{g} / \mathrm{mL}$ punicalagin standard (Graphs 1A and B). Using the regression equation from the calibration curve, it was quantified that the total amount of punicalagin in the sample is an average of $2023.58 \pm 25.29 \mu \mathrm{g} / \mathrm{mL}$ per $500 \mathrm{mg} / \mathrm{mL}$ aqueous PG extract.
Table 1: Summary of the results for the linearity of standard and HPLC method validation for total punicalagin (punicalagin $A+$ punicalagin $B$ )

\begin{tabular}{lll}
\hline Criteria & Obtained values & $\begin{array}{l}\text { Acceptance } \\
\text { criteria }\end{array}$ \\
\hline Linearity range & $25-200 \mu \mathrm{g} / \mathrm{mL}$ & $\mathrm{N} / \mathrm{A}$ \\
Regression equation & $\mathrm{y}=152.8 \mathrm{x}-2073$ & $\mathrm{~N} / \mathrm{A}$ \\
Slope of calibration curve $(\mathrm{m})$ & 152.8 & $\mathrm{~N} / \mathrm{A}$ \\
Correlation coefficient $\left(\mathrm{R}^{2}\right)$ & 0.999 & $\begin{array}{l}\text { Not less } \\
\text { than } 0.99\end{array}$ \\
& & $<25 \mu \mathrm{g} / \mathrm{mL}$ \\
Limit of detection & $13.56 \mu \mathrm{g} / \mathrm{mL}$ & $<25 \mu \mathrm{gL}$ \\
Limit of quantification & $13.57 \mu \mathrm{m} / \mathrm{mL}$ & $\leq 2 \% \mathrm{RSD}$ \\
Precision & $0.03-1.04 \%$ & $95-105 \%$ \\
Accuracy & $98.68-102.79 \%$ &
\end{tabular}

N/A: Not applicable; RSD: Relative standard deviation

\section{Minimum Bactericidal Concentration}

The MBC results for PG extract in distilled water showed inhibition of different bacteria at various concentrations. The MBC for the tested bacteria were the following: $250 \mathrm{mg} / \mathrm{mL}$ for S. mutans, $125 \mathrm{mg} / \mathrm{mL}$ for S. sanguinis and $500 \mathrm{mg} / \mathrm{mL}$ for L. casei.

\section{Time-kill Assay}

Results showed that for all three strains, $500 \mathrm{mg} / \mathrm{mL}$ aqueous PG extract equivalent to punicalagin $2023.58 \pm$ $25.29 \mu \mathrm{g} / \mathrm{mL}$ can cause an increase in reduction of total viable colonies with time as compared to negative control (Graph 2). There was total bacterial growth inhibition of S. mutans at 6 hours (Graph 2A); S. sanguinis at 1 hour (Graph 2B) and L. casei at 24 hours (Graph 2C).

\section{Agar Well Diffusion}

The results as shown in Table 2 revealed that for S. mutans, there is a significant difference in all three gels where the mean ZOI of CHX gel > PG gel > blank gel. For S. sanguinis,
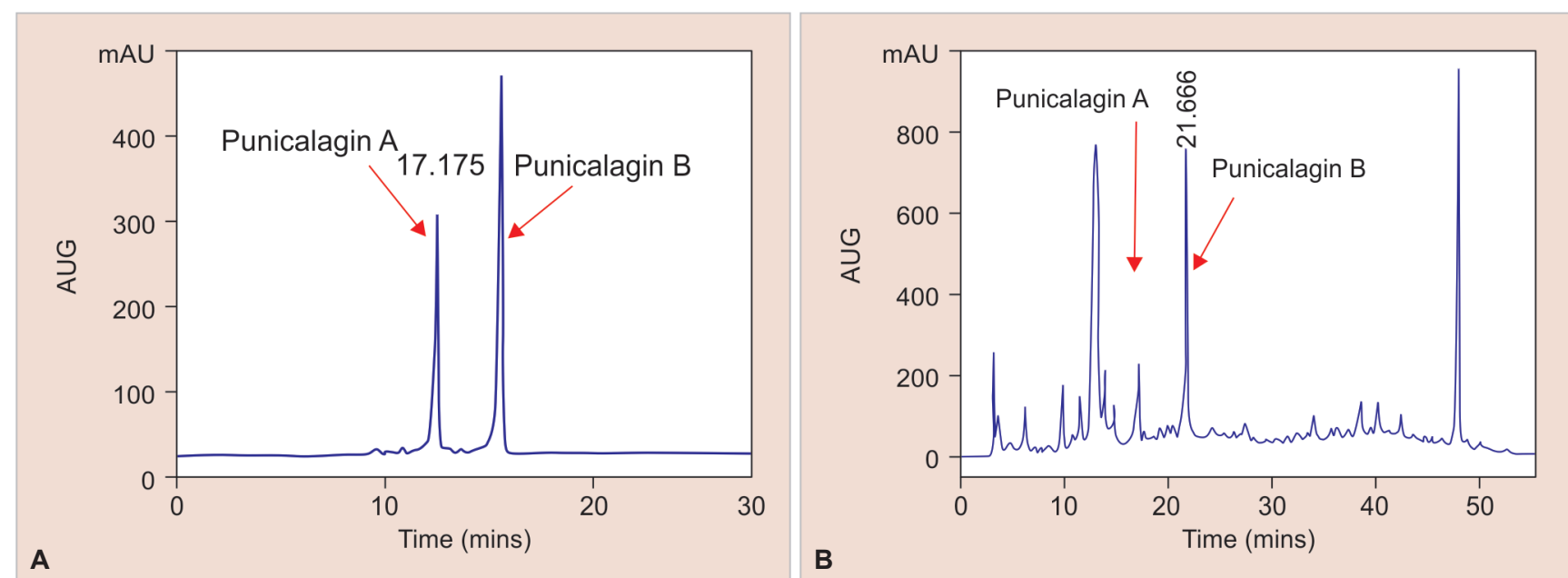

Graphs 1A and B: High Performance Liquid Chromatography chromatogram of $200 \mu \mathrm{g} / \mathrm{mL}$ punicalagin (A) and $50 \mathrm{mg} / \mathrm{mL}$ diluted aqueous PG extract sample; and (B) showing similar retention time of punicalagin $A$ at the 17 minute range and punicalagin $B$ at the 21 minute range 

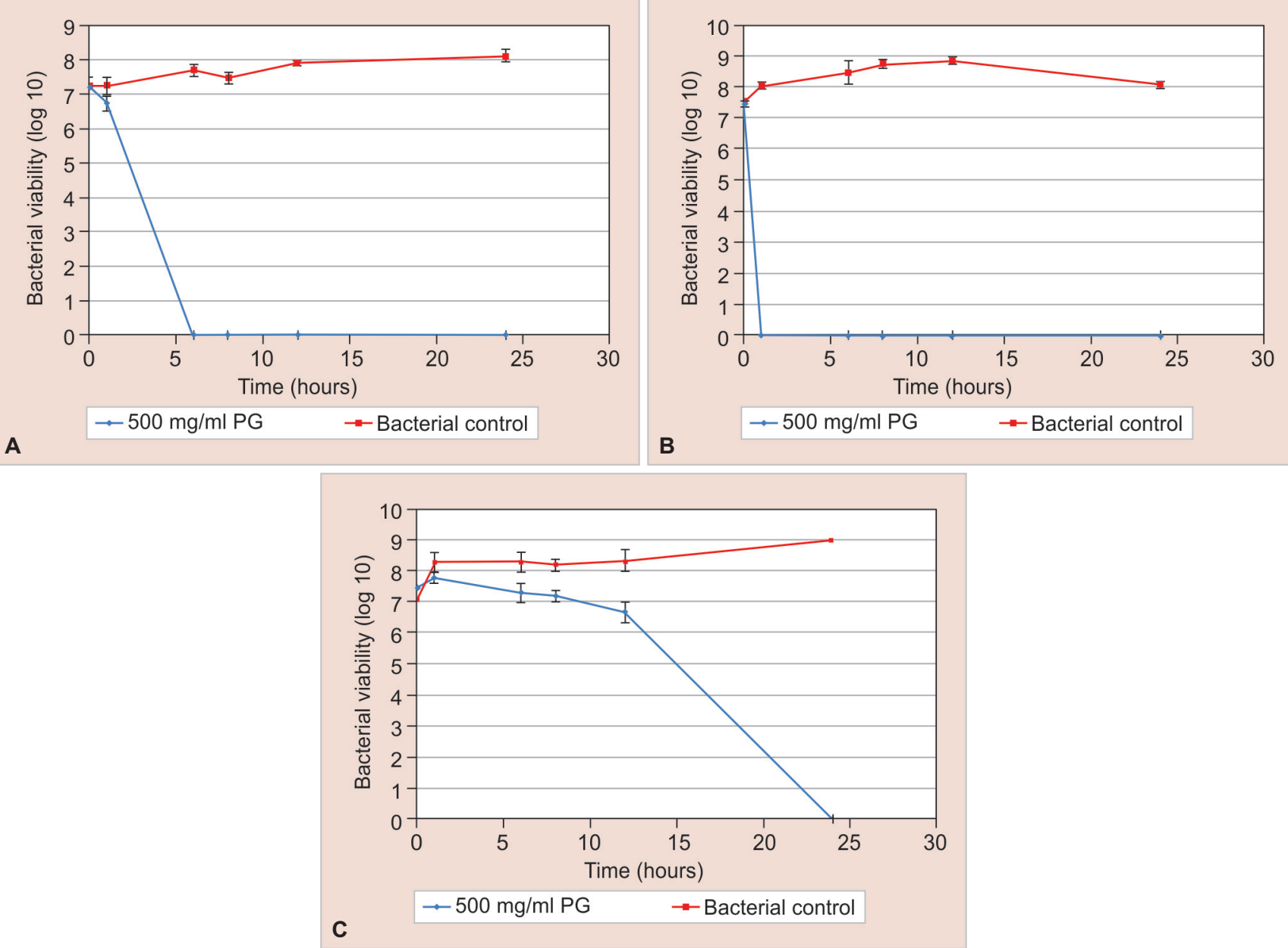

Graphs 2A to C: Time-kill curves for (A) S. mutans; (B) S. sanguinis; and (C) L. casei treated with $500 \mathrm{mg} / \mathrm{mL}$ aqueous $P G$ extract. The graph is plotted as the logarithm of the number of remaining viable cells $\left(\log _{10} \mathrm{CFU} / \mathrm{mL}\right)$ against time

Table 2: Zones of inhibition of the three gels in each of the tested bacterial strains

\begin{tabular}{llll}
\hline & \multicolumn{3}{c}{ Zones of Inhibition } \\
\cline { 2 - 4 } Gel & S. mutans Mean $\pm S D(\mathrm{~mm})$ & S. sanguinis Mean $\pm S D(\mathrm{~mm})$ & L. casei Mean $\pm S D(\mathrm{~mm})$ \\
\hline PG & $16.72+2.32^{\mathrm{b}}$ & $24.5 \pm 7^{\mathrm{b}}$ & 0 \\
CHX & $31.18 \pm 2.89^{\mathrm{a}, \mathrm{b}}$ & $26.66 \pm 5.57^{\mathrm{b}}$ & $22.88 \pm 3.1^{\mathrm{a}, \mathrm{b}}$ \\
Blank & 0 & 0 & 0 \\
\hline
\end{tabular}

SD: Standard deviation; Note: PG gel = 0.34\% punicalagin (w/w); CHX gel = 2\%; Level of significance set at $p=0.05 ; a=$ statistically significant higher mean ZOI than PG gel by means of one way repeated measures ANOVA $(p<0.001) ; b=$ statistically significant higher mean ZOI than blank gel by means of one way repeated measures ANOVA $(p<0.001)$

CHX gel $=$ PG gel $(\mathrm{p}=0.101)>$ blank gel. For L. casei, CHX gel $>$ PG gel whereas PG gel = blank gel. Comparison of the PG gel potency against the tested bacteria showed that the mean ZOI in S. sanguinis = S. mutans $(\mathrm{p}=0.118)$; L. casei $<$ S. mutans and S. sanguinis.

\section{DISCUSSION}

Crude PG extract cannot dissolve completely in most solvents, therefore, the identification and quantification of the bioactive ingredient in the sample is important. Focus was placed on punicalagin as the main active ingredient since it is completely soluble in water. In addition, the punicalagin used in this study was below the toxic level for punicalagin recorded in literature. ${ }^{14,18,21,22}$ Several studies have concluded that the antimicrobial effect of pomegranate was due to the inhibitory activity exhibited by punicalagin against different tested bacteria and fungi. ${ }^{18,22}$

The results of the agar well diffusion experiment showed that the formulated PG gel exhibited a statistically significant greater inhibition in S. mutans than the negative control but at a significantly lesser inhibition than CHX. The PG gel may not be the gold standard in inhibiting S. mutans, however, it is able to reduce the growth of S. mutans significantly more than the negative control. Several studies have shown that PG extracted 
from different parts of the plant can inhibit $S$. mutans at various dilutions, such as $1: 8$ and $1: 16 \mathrm{mg} / \mathrm{mL}$ with results comparable to the inhibition by $\mathrm{CHX} .{ }^{16,23}$ In a recent in vitro study, pomegranate pulp gel showed highly significant inhibitory effect against $S$. mutans at concentrations ranging from 5 to $100 \% \mathrm{w} / \mathrm{v}^{24}$ There was also another study which showed that $500 \mathrm{mg} / \mathrm{mL}$ aqueous PG extract presented with a mean ZOI of $23 \mathrm{~mm} .{ }^{25}$ These experimental results from other studies supported the results of this study on $S$. mutans susceptibility to PG extract.

Streptococcus sanguinis was also found to be sensitive to pomegranate extract. The MBC of PG extract for $S$. sanguinis was $125 \mathrm{mg} / \mathrm{mL}$ which was the lowest among the three tested bacteria and required only 1 hour contact time at $4 \times \mathrm{MBC}(500 \mathrm{mg} / \mathrm{mL})$ for complete inhibition of this bacterial strain. Agar well diffusion results showed that the formulated PG gel exhibited a zone of inhibition in S. sanguinis similar to the inhibition caused by CHX gel which is in agreement with previous studies that PG gel/extract at $1: 8$ and $1: 16 \mathrm{mg} / \mathrm{mL}$ dilution presented an inhibitory activity on $S$. sanguinis in a similar or greater efficiency than the positive control. ${ }^{16,23}$ The previous studies were also in agreement with the results of this study that there was no difference in the effectiveness of PG in inhibiting the growth of $S$. mutans and S. sanguinis. ${ }^{16,23}$

For L. casei, the data gathered in the MBC and timekill assay experiments showed that its growth can be completely inhibited by $500 \mathrm{mg} / \mathrm{mL}$ aqueous PG extract at 24 hours incubation time. However, results from the Agar well diffusion experiments have shown that the same concentration of PG in gel form cannot inhibit $L$. casei at 24 hour incubation period. These negative inhibitory results were in agreement with the results of some studies which concluded that lactobacilli, such as L. casei were generally not affected by ellagitannins (punicalagin) from commercially available pomegranate extract. ${ }^{26,27}$ This was further supported by studies which claimed that berries and their phenolic extracts contain organic acids and their addition to the culture media lowered the pH which favors the growth of Lactobacillus species. ${ }^{26,28}$ However, the results of the study by Devi claimed that the ZOI of $500 \mathrm{mg} / \mathrm{mL}$ PG in Lactobacillus is $19 \mathrm{~mm}$ which suggests that the aqueous PG extract does have an effect on L. casei inhibition. ${ }^{25}$ There is a need for further studies using increased concentrations of the PG gel as well as increased contact time to confirm the antibacterial activity of the formulated PG gel against L. casei.

The inhibitory activities on bacterial growth and adhesion can also be explained by the mechanism of action of PG extract. The tannins which are chemical compounds that precipitate protein, crosses over the cell wall of the microorganisms and binds to its surface leading to the precipitation of membrane proteins which can result in microbial cell lysis. The formation of complexes with cell wall proteins also decreases cell wall permeability and reduces the transport of substrates into the microbial cell. Tannins could also inhibit important bacterial enzymes, such as glucosyltransferase which is important for binding of the bacteria to the tooth surface as well as to each other and if disrupted, it prevents the adherence mechanism of these organisms to tooth surface. ${ }^{12,26,29}$ Another mechanism used by PG extract is the binding of phenolic compounds to carbohydrates and physiological metal ions, such as iron and copper making them unavailable for the microorganisms which affect the activity of metalloenzymes resulting in cell wall disruption. Polyphenols can also significantly affect the bacterial population by decreasing the $\mathrm{pH}$ of the environment. ${ }^{12,26,29}$ Although several studies have concluded that punicalagin is the major active constituent responsible for the antibacterial activity of PG, Lalwani et al stated that the synergistic effect of PG constituents is responsible for the anticariogenic effect of PG. ${ }^{29}$

\section{CONCLUSION}

The PG gel tested in this study produced an inhibitory activity on S. mutans and S. sanguinis but not on L. casei within 24 hours incubation period. The findings of this study support that $500 \mathrm{mg} / \mathrm{mL}$ PG gel equivalent to $0.234 \%$ punicalagin $(\mathrm{w} / \mathrm{w})$ can possibly be used and is a potential candidate for the prevention of dental caries. Further in vitro biofilm and clinical research is needed to identify the real benefits of PG extract in gel form as a chemotherapeutic and preventive agent for dental caries.

\section{ACKNOWLEDGMENT}

Authors would like to thank the Graduate Education and Research Program funded by the Faculty of Dentistry and Graduate School, Khon Kaen University, Thailand.

\section{REFERENCES}

1. Do LG. Distribution of caries in children: variations between and within populations. J Dent Res 2012 Jun;91(6):536-543.

2. Kassebaum NJ, Bernabe E, Dahiya M, Bhandari B, Murray CJ, Marcenes W. Global burden of untreated caries: a systematic review and metaregression. J Dent Res 2015 May;94(5): 650-658.

3. Vahabi S, Najafi E, Alizadeh S. In vitro antimicrobial effects of some herbal essences against oral pathogens. J Med Plant Res 2011 Sep;5(19):4870-4878.

4. Kim JE, Kim HE, Hwang JK, Lee HJ, Kwon HK, Kim BI. Antibacterial characteristics of Curcuma xanthorrhiza extract on Streptococcus mutans biofilm. J Microbiol 2008 Apr;46(2): 228-232. 
5. Liljemark WF, Bloomquist C. Human oral microbial ecology and dental caries and periodontal diseases. Crit Rev Oral Biol Med 1996;7(2):180-198.

6. Callaway A, Kostrzewa M, Willershausen B,SchmidtF, ThiedeB,

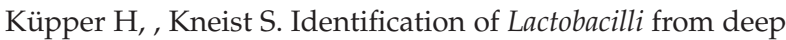
carious lesions by means of species-specific PCR and MALDITOF mass spectrometry. Clin Lab 2013;59(11-12):1373-1379.

7. Svec $\mathrm{P}$, Sedlácek I, Zácková L, Nováková D, Kukletová M. Lactobacillus spp. associated with early childhood caries. Folia Microbiol (Praha). 2009;54(1):53-58.

8. Tardif G, Sulavik MC, Jones GW, Clewell DB. Spontaneous switching of the sucrose-promoted colony phenotype in Streptococcus sanguinis. Infect Immun 1989 Dec;57(12):3945-3948.

9. Yamaguchi M, Terao Y, Ogawa T, Kawabata S. Role of Streptococcus sanguinis sortase A in bacterial colonization. Micro Infect 2006 Nov;8(12-13):2791-2796.

10. Devi A, Singh V, Bhatt AB. Antibiotic sensitivity pattern of Streptococcus against commercially available drugs and comparison with extract of Punica granatum. Int J Pharm Sci Res 2011 Jan;2(2):504-508.

11. Twetman S. Antibacterial agents for prevention and therapy of early childhood caries. Oralprophylaxe Kinderzahnheilkunde 2010;32(2):68-72.

12. Ismail T, Sestili P, Akhtar S. Pomegranate peel and fruit extracts: a review of potential anti-inflammatory and antiinfective effects. J Ethnopharmacol 2012 Sep 28;143(2):397-405.

13. Gaig P, Bartolome B, Lleonart R, Garcia-Ortega P, Palacios R, Richart C. Allergy to pomegranate (Punica granatum). Allergy 1999 Mar;54(3):287-288.

14. Patel C, Dadhaniya P, Hingorani L, Soni MG. Safety assessment of pomegranate fruit extract: acute and subchronic toxicity studies. Food Chem Toxicol 2008 Aug;46(8):2728-2735.

15. Vidal A, Fallarero A, Peña BR, Medina ME, Gra B, Rivera F, Gutierrez Y, Vuorela PM. Studies on the toxicity of Punica granatum L. (Punicaceae) whole fruit extracts. J Ethnopharmacol 2003 Dec;89(2-3):295-300.

16. Vasconcelos LC, Sampaio FC, Sampaio MC, Pereira Mdo S, Higino JS, Peixoto MH. Minimum inhibitory concentration of adherence of Punica granatum Linn (pomegranate) gel against S. mutans, S. mitis and C. albicans. Braz Dent J 2006;17(3): 223-227.

17. Machado TB, Pinto AV, Pinto MC, Leal IC, Silva MG, Amaral AC, Kuster RM, Netto-dosSantos KR. In vitro activity of Brazilian medicinal plants, naturally occurring naphthoquinones and their analogues, against methicillin-resistant Staphylococcus aureus. Int J Antimicrob Agents 2003 Mar;21(3):279-284.
18. Abdollahzadeh Sh, Mashouf R, Mortazavi H, Moghaddam M, Roozbahani N, Vahedi M. Antibacterial and antifungal activities of Punica granatum peel extracts against oral pathogens. J Dent (Tehran) 2011Winter;8(1):1-6.

19. Madrigal-Carballo S, Rodríguez G, Krueger CG, Dreher M, Reed JD. Pomegranate (Punica granatum) supplements: authenticity, antioxidant and polyphenol composition. J Funct Foods 2009;1(3):324-329.

20. Goud MV, Rao AS, Ranjan SP, Shalini SD, Sowmya S, Bhoga B. method development and validation of RP-HPLC method for assay of sildosin in pharmaceutical dosage form. Int J Pharma Sci 2013 Mar;3(2):194-196.

21. Cerdá B, Llorach R, Cerón JJ, Espín JC, Tomás-Barberán FA. Evaluation of the bioavailability and metabolism in the rat of punicalagin, an antioxidant polyphenol from pomegranate juice. Eur J Nutr 2003 Jan;42(1):18-28.

22. Machado TB, Leal ICR, Amaral ACF, dos Santos KRN, da Silva MG, Kuster RM. Antimicrobial ellagitannin of punica granatum fruits. J Braz Chem Soc 2002 Sep-Oct;13(5):606-610.

23. Pereira JV, Pereira MSV, Sampaio FC, Sampaio MCC, Alves PM, de Araújo CRF, Higino JS. In vitro antibacterial and antiadherence effect of Punica granatum Linn extract upon dental biofilm microorganisms. Rev Bras Farmacogn 2006 Jan-Mar16(1):88-93.

24. Subramaniam P, Dwivedi S, Uma E, Girish Babu KL. Effect of pomegranate and Aloe vera extract on Streptococcus mutans: An in vitro study. Dent Hypotheses 2012 Nov;3(3):99-105.

25. Devi A, Singh V, Bhatt AB. Comparative antibacterial study of different extract of pomegranate and its wild variety. Int J Pharm Sci Res. 2011;2(10):2647-2650.

26. Bialonska D, Kasimsetty SG, Schrader KK, Ferreira D. The effect of pomegranate (Punica granatum L.) byproducts and ellagitannins on the growth of human gut bacteria. J Agr Food Chem 2009 Sep 23;57(18):8344-8349.

27. Landete JM. Ellagitannins, ellagic acid and theri derived metabolites: A review about source, metabolism, functions and health. Food Res Int 2011 Jun;44(5):1150-1160.

28. Puupponen-Pimiä R, Nohynek L, Alakomi HL, OksmanCaldentey KM. Bioactive berry compounds-novel tools against humanpathogens. Appl Microbiol Biotechnol 2005 Apr;67(1):8-18.

29. Lalwani V, Koneru A, Vanishree M, Vardendra M, Hunasgi S, Surekha R. Anti-microbial activity of Punica granatum on Streptococcus in dental caries patients and healthy individuals: a comparative study. J Adv Clin Res In 2014 Nov-Dec;1(3): 94-98. 